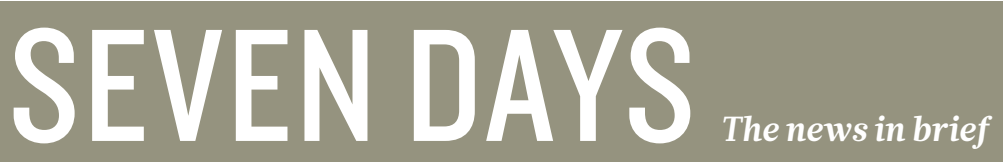

RESEARGH

\section{Sea-floor maps}

The Australian government released detailed bathymetric data covering 120,000 square kilometres of the sea floor on 19 July. The data were collected during its search for missing Malaysia Airlines flight MH370, which vanished in the Indian Ocean shortly after take-off in March 2014. Although ocean data collected during the search did not turn up the missing aircraft, the information gives scientists a vivid view of the tectonic ridges, volcanoes and valleys that lie beneath the ocean's surface. The high-resolution sonar images could aid climate and tsunami modelling and help researchers to learn more about the geological activity that has rocked the ocean floor for millions of years.

\section{FUNDING}

\section{Gene-drive cash}

The US Defense Advanced Research Projects Agency (DARPA), the US government's high-risk research arm, has awarded US\$65 million in funding to scientists studying geneediting technologies. Most of the money will support work on gene drives, a geneticengineering technology that could swiftly spread modifications through entire wild populations. Researchers will seek to develop tools to counter the misuse of gene drives. See page 388 for more.

\section{POLICY}

\section{HIV/AIDS milestone}

For the first time in history, more than half of all people living with HIV or AIDS -19.5 million of about 36.7 million individuals are receiving antiretroviral

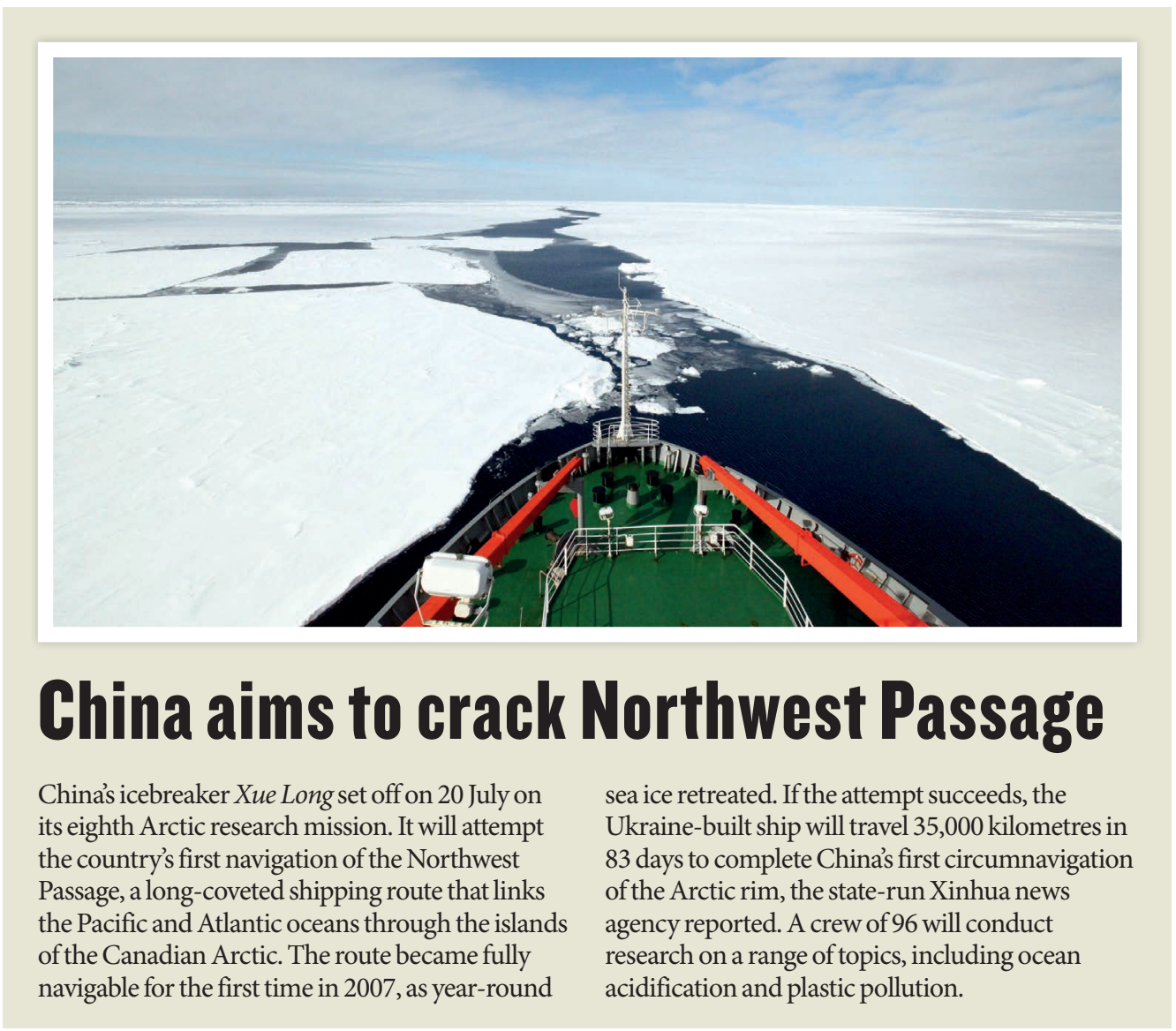

therapy, the Joint United Nations Programme on HIV/ AIDS reports. Between 2010 and 2016, new HIV infections around the world dropped by $16 \%$, and AIDS-related deaths decreased by $32 \%$. The update, released on 20 July, said that the main reasons for progress were improved access to treatment, including early treatment for people diagnosed with HIV, as well as prevention programmes. The report noted that the world is on track to reach a UN goal of increasing the number of people receiving treatment to 30 million by 2020 .

\section{Climate law}

On 17 July, lawmakers in California approved legislation that extends the state's cap-andtrade emissions programme until 2030. The climate programme, which launched in 2012 and was set to run until 2020 , covers major energy and industrial facilities that account for roughly $85 \%$ of the state's greenhouse-gas emissions. Governor Jerry Brown, who pushed for the legislation, hailed the vote as a courageous act to confront "the existential threat of our time". California law requires the state to reduce emissions to $40 \%$ below 1990 levels by 2030, and the state has set a goal of reducing emissions by $80 \%$ by 2050 .

\section{Biosecurity review}

The White House is planning to develop a comprehensive biosecurity strategy for the United States, homeland security adviser Thomas Bossert said on 20 July. According to Reuters, the effort would be the first of its kind in the nation's history and would outline a governmentwide response to pandemics and bioterrorism threats such as the 2001 anthrax attacks, which killed five people. Bossert said it would be published "as soon as we can". The Trump administration has been criticized for its approach to biosecurity, which has included proposed budget cuts to global-health programmes and its plans to close two biodefence research labs in Maryland.

\section{EVENTS}

\section{Discrimination suit}

A female scientist is suing the Salk Institute for Biological Studies in La Jolla, California, for gender discrimination the third such case brought against the institution this 
$\circ$ month. Cancer researcher

Beverly Emerson filed suit

O on 18 July in the California

Superior Court, claiming that

Salk had denied promotions

and funding to her and the

two other women who are

suing the institute separately.

Only 4 of Salk's 32 tenured

faculty members are female.

Emerson's suit references a

2003 internal Salk report,

which allegedly found that

female faculty members were promoted more slowly than men. Salk president Elizabeth Blackburn has said that the initial pair of lawsuits "misrepresented" the institute.

\section{PEOPLE}

\section{Research chief quits}

The president and chief executive of the French National Research Agency (ANR), Michael Matlosz, resigned on 21 July after more than a year of widely reported discontent with how the funding body was being managed. Matlosz (pictured), a former chemical engineer who was promoted to the post in 2014, left because the agency needed "a new impetus" following organizational changes, according to an 18 July statement by Frédérique Vidal, France's minister for higher education, research and innovation. Arnaud Torres,

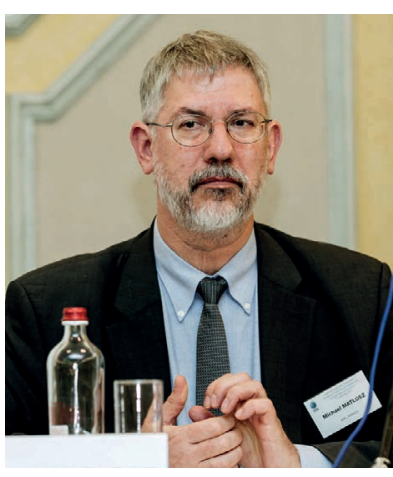

an ANR director, is serving as interim chief until a new head is found. See go.nature. com/2uuprm7 for more.

\section{Seismic charges}

A South Korean earthquake researcher has been convicted by a US court over a moneylaundering and bribery scheme. From 2009 to 2015, Heon-Cheol Chi, a former director of the Earthquake Research Center at the Korea Institute of Geoscience and Mineral Resources (KIGAM) in Daejeon, used his position to collect more than US\$1 million in bribes from seismology companies. In exchange, he helped them to secure contracts from KIGAM and South Korean companies, according to the evidence presented at trial.

\section{Agriculture pick}

US President Donald Trump intends to nominate former conservative talk-show host and economics professor Samuel Clovis to become the chief scientist at the US Department of Agriculture. The 19 July announcement caused controversy because Clovis, a climate-change sceptic and adviser to the president, is not a scientist. By law, the USDA chief scientist - formally known as the undersecretary for research, education and economics - prioritizes the agency's research programme and must be selected from "distinguished scientists" with agricultural expertise. Clovis's nomination must be confirmed by the Senate before he can take his post.

\section{TECHNOLOGY}

\section{China Al plans}

On 20 July, China released ambitious plans to become the world leader in artificial intelligence (AI) by 2030. A document posted online by the State Council, China's powerful central administrative authority, laid out a road map to develop basic research capabilities and application and commercialization strategies. The scheme lists a range of potential AI applications — including traffic control, environmental protection and public security - as well as a host of medical applications such as robotic surgery and

\section{TREND WATCH}

Most cases of alleged sexual harassment at US universities involve physical, rather than verbal, harassment, according to a study. Researchers analysed some 300 cases of faculty members harassing students, identified from media reports, civil investigations and lawsuits (N. C. Cantalupo and W. C. Kidder Preprint at http://go.nature. com/2uvqu33; 2017). In 53\% of cases, staff members were accused of harassing more than one student. See page 379 for more.

\section{SEXUAL HARASSMENT AT US UNIVERSITIES}

An analysis of some 300 cases of alleged student sexual harassment by US faculty members finds that more than half of these involve staff members accused of harassing more than one student.

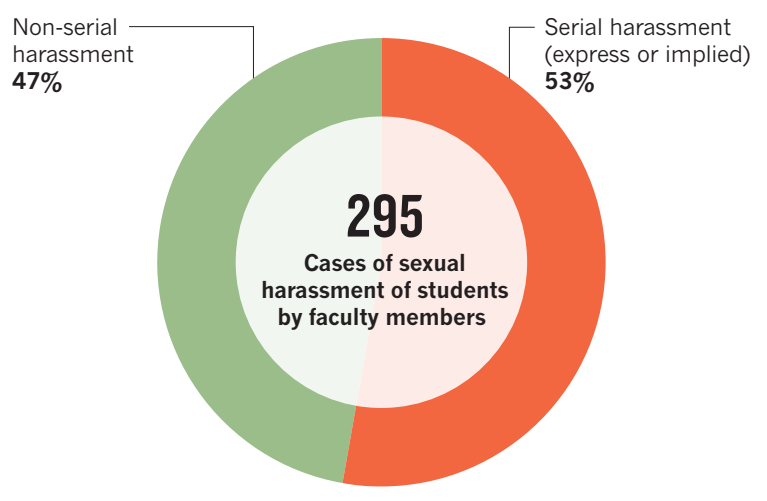

drug development. It also lists dual-use technologies, suitable for military purposes. The document didn't mention any new funds for the plans, but says that China hopes to achieve an "intelligent" economy and society by 2030 .

\section{ENVIRONMENT}

\section{Gove's green Brexit}

UK environment secretary Michael Gove has pledged to place the country's agricultural and fisheries policies on a more scientific footing after Brexit. Gove said in a 21 July speech that once the United Kingdom is no longer part of the European Union's Common Agricultural Policy, which pays UK farmers around $£ 3$ billion (US $\$ 3.9$ billion) per year in subsidies, his government would ensure that farmers receive similar levels of support until 2022. However, these payments will be increasingly linked to protecting the environment as well as supporting food production. Gove also pledged to make fisheries more sustainable after the country exits the EU Common Fisheries Policy.

\section{Ocean treaty}

Conservation groups have welcomed a United Nations decision to work towards creating a treaty to protect marine life in the high seas. Regulation of activities such as fishing and mining on the high seas - areas of the ocean beyond the jurisdiction of national governments - has become an increasingly hot topic in recent years. On 21 July, a 'preparatory committee' at the UN in New York City agreed to recommend to the organization's General Assembly that an international conference on the issue should be called in 2018 , a step towards a binding treaty. 